\title{
Predictive Factors for Non-Sentinel Lymph Node Metastasis in Patients with ACOSOG Z0011 Criteria
}

\author{
Carlos Martin Loza ${ }^{a}$ Pablo Mandób,c Carolina Ponce ${ }^{a}$ Federico Colóa $^{a}$ \\ Veronica Fabiano ${ }^{a}$ Jose Loza $^{a}$ Maria Victoria Costanzo ${ }^{a}$ Adrian Nervo $^{a}$ Jorge Nadal $^{a}$ \\ Anibal Nuñez de Pierro ${ }^{d}$ Reinaldo Chacon ${ }^{a}$ RCM Database Contributors \\ a Instituto Alexander Fleming, Buenos Aires, Argentina; \\ ${ }^{b}$ Fundación Cancer-FUCA, Buenos Aires, Argentina; \\ ${ }^{\mathrm{C}} \mathrm{CEMIC}$, Buenos Aires, Argentina; \\ ${ }^{\mathrm{d}}$ Hospital JA Fernandez, Buenos Aires, Argentina
}

Keywords

Breast cancer - Sentinel lymph node biopsy . Lymphatic metastasis

\section{Summary}

Background: Nodal staging constitutes an element of great importance in the treatment planning for early breast cancer. The ACOSOG Z0011 trial demonstrated that sentinel lymph node (SLN) biopsy alone results in rates of local control, disease-free survival, and overall survival equivalent to those seen after axillary lymph node dissection. The purpose of this study was to determine the rate of patients that fulfill the ACOSOG Z0011 inclusion criteria and to define predictive factors for nonSLN positivity. Methods: A retrospective analysis of the breast surgery database of the Argentinian Society of Mastology was carried out. Patients were selected if they fulfilled the ACOSOG Z0011 inclusion criteria. The association of clinical and pathological factors with non-SLN positivity was evaluated in univariate and multivariate analysis. Results: Among 8,262 patients, 973 had positive SLN, and 348 satisfied the inclusion criteria. Histological grade (G3 vs. G1-2, odds ratio (OR) 1.81; $p=0.024$ ), tumor size (T2 vs. T1, OR 2.39; $p=0.001$ ), and age ( $>50$ vs. $<50$ years, OR 1.95; $p=0.007$ ) were associated with non-SLN positivity in multivariate analysis. Conclusion: Although the clinical relevance of our data is not established, older women with tumors bigger than $2 \mathrm{~cm}$ and/or high histological grade are at greater risk of having metastatic disease in the lymph nodes if axillary lymph node dissection is avoided. This subgroup of patients represents only $30 \%$ of the trial population.

() 2018 S. Karger GmbH, Freiburg

\section{Introduction}

Nodal staging constitutes an element of great importance in the treatment planning for patients with early breast cancer. Sentinel lymph node (SLN) biopsy (SLNB) is the standard practice for patients with clinically negative axillary evaluation due to its high identification rate and high negative predictive value [1]. In 2010, the ACOSOG Z0011 trial [2] demonstrated in a highly selected group of patients with only 1 or 2 positive SLN that SLNB alone resulted in rates of local control, disease-free survival, and overall survival equivalent to those seen after axillary lymph node dissection (ALND), but with significantly lower morbidity. Although the National Comprehensive Cancer Network recommends considering no further surgery beyond SLNB for patients meeting ACOSOG Z0011 eligibility criteria according to those results, in Argentina standard practice still includes ALND when macrometastasis is detected in the SLN. The ACOSOG Z0011 trial included women with T1-2 tumors treated with breast conserving surgery (BCS) and with 1 or 2 positive SLN, presuming a low-risk population. In consequence, applying these criteria to the general population of women with breast cancer must be done with caution and may need more evaluation [3-5].

Accurate prediction of non-SLN positivity may help to select patients benefiting from being spared ALND; however, the ACOSOG Z0011 results have raised doubts as to its value as no effect on survival was observed. Several studies have proposed clinical and pathologic factors (tumor size, number of positive SLN, and age) as predictive factors for more extensive axillary involvement [6-12]. Nevertheless, quality data is still missing in order to propose possible practice changes.

The purpose of this study was to determine the rate of breast cancer patients that fulfilled the ACOSOG Z0011 criteria and clini-

\section{KARGER}

() 2018 S. Karger GmbH, Freiburg

Fax +497614520714 
cal characteristics. Additionally, patient and tumor characteristics were analyzed in order to define predictive factors for non-SLN positivity and the possible risks of avoiding ALND in these patients.

\section{Patients and Methods}

A retrospective analysis of the Breast Cancer Registry ('Registro de Cáncer de Mama', RCM) of the Argentinian Society of Mastology was carried out. This electronic database was initiated in 2010 and includes the collaboration of public and private centers of different Argentinean cities including Buenos Aires, La Plata, Cordoba, and Tucuman. The ethnic background of Argentina's population is Caucasian in its majority.

All patients included in the RCM database gave signed informed consent before surgery allowing to share their data.

\section{Inclusion and Exclusion Criteria}

Patients' fulfillment of ACOSOG Z0011 was defined by the following inclusion criteria: women aged 18 or more, with histologically confirmed invasive breast carcinoma clinically measuring $5 \mathrm{~cm}$ or less, no palpable adenopathies, treated with lumpectomy with negative margins, and SLN labelled with technetium and blue dye with metastasis documented by frozen section, touch preparation, or hematoxylin-eosin staining on formalin-fixed paraffin-embedded samples. All patients received whole breast external beam radiotherapy. $\mathrm{Pa}-$ tients were excluded if they had 3 or more positive SLN, matted nodes, or gross extranodal disease, or if they had received neoadjuvant endocrine therapy or chemotherapy.

\section{Statistical Analysis}

Categorical variables were expressed as absolute numbers and percentages. Continuous variables were described in terms of means and standard deviations if normally distributed, or medians and interquartile ranges (IQR) otherwise. Comparisons between groups were conducted using the Student t-test and the Wilcoxon rank sum test for continuous variables, and the chi-square test and Fisher's exact test for categorical variables. The relationships between each of the variables and non-SLN involvement were assessed individually using univariate analysis. The variables that were assessed as statistically significant in univariate analysis were included in multivariate analysis. Multivariate logistic regression was used to determine factors predictive of nonSLN involvement. A p value of $<0.05$ was considered statistically significant. Statistical analysis was carried out with Stata 11 (StataCorp, College Station, TX, USA).

\section{Results}

The database included 8,262 patients with breast cancer stage I-III. Of the patients with surgical axillary procedures, $51.89 \%$ ( $\mathrm{n}=$ $4,287)$ had an SLN evaluation of which $22.7 \%(n=973)$ where positive. Following the criteria of ACOSOG Z0011, 348 patients were included. The clinical characteristics of this group are described in table 1.

Patients had a median of 2 (IQR 1-2) SLN resected and a median of 1 (IQR 1-1) positive SLN. 47 (13.51\%) patients had micrometastasis in the SLN. Patients with positive SLN underwent ALND with a median of 12 (IQR 10-16) non-SLN resected. When further ALND was carried out, 52.3\% $(\mathrm{n}=182)$ had metastatic disease in non-SLN.
Table 1. Baseline characteristics

\begin{tabular}{|c|c|}
\hline \multicolumn{2}{|l|}{ Characteristics } \\
\hline Patients, $\mathrm{n}$ & 348 \\
\hline Age, years ${ }^{\mathrm{a}}$ & $55.34 \pm 11.53$ \\
\hline \multicolumn{2}{|l|}{ Menopausal status, n (\%) } \\
\hline Premenopausal & $121(34.77)$ \\
\hline Postmenopausal & $212(60.92)$ \\
\hline Unknown & $15(4.31)$ \\
\hline $\begin{array}{l}\text { Family history of breast cancer, } \\
\qquad \mathrm{n}(\%)\end{array}$ & $77(22.13)$ \\
\hline Breast tumor size, $\mathrm{mm}^{\mathrm{b}}$ & $20(15-25)$ \\
\hline $\begin{array}{l}\text { Breast-conserving surgery, } \\
\mathrm{n}(\%)\end{array}$ & $348(100)$ \\
\hline \multicolumn{2}{|l|}{ Histologic subtypes, n (\%) } \\
\hline Ductal & $274(78.74)$ \\
\hline Lobular & $46(13.22)$ \\
\hline Ductolobular & $13(3.74)$ \\
\hline Other & $15(4.32)$ \\
\hline \multicolumn{2}{|l|}{ Histological grade, $\mathrm{n}(\%)$} \\
\hline 1 & $57(16.38)$ \\
\hline 2 & $146(41.95)$ \\
\hline 3 & $116(33.33)$ \\
\hline Unknown & $29(8.33)$ \\
\hline $\begin{array}{l}\text { Lymphovascular invasion, } \\
\text { n (\%) }\end{array}$ & $158(45.40)$ \\
\hline \multicolumn{2}{|l|}{ Estrogen receptor-positive } \\
\hline $\mathrm{n}(\%)$ & $298(85.63)$ \\
\hline Median $^{\mathrm{b}}$ & $90(60-98)$ \\
\hline \multicolumn{2}{|l|}{ Progesterone receptor-positive } \\
\hline $\mathrm{n}(\%)$ & $281(80.75)$ \\
\hline Median $^{\mathrm{b}}$ & $70(38-90)$ \\
\hline \multicolumn{2}{|l|}{ HER2, n (\%) } \\
\hline Positive & $44(12.64)$ \\
\hline Negative & $304(77.36)$ \\
\hline \multicolumn{2}{|l|}{ Phenotype, n (\%) } \\
\hline Luminal & $276(79.31)$ \\
\hline HER2 & $44(12.64)$ \\
\hline Triple-negative & $20(5.75)$ \\
\hline Not classified & $8(2.30)$ \\
\hline \multicolumn{2}{|c|}{$\begin{array}{l}{ }^{\mathrm{a}} \text { Mean } \pm \text { standard deviation. } \\
{ }^{\mathrm{b}} \text { Median (interquartile range). } \\
\text { HER2 = Human epidermal growth factor } \\
\text { receptor } 2 .\end{array}$} \\
\hline
\end{tabular}

Univariate Analysis of Factors Associated with Non-SLN Positivity Clinical and pathologic variables were analyzed in order to determine its possible association with residual axillary metastatic disease after SLN dissection. Results are shown in table 2.

Histological grade, tumor size, age older than 50 years, and postmenopausal status showed significant association with non-SLN positivity. As can be seen in figure $1 \mathrm{~A}$, histological grade shows clear differences between patients with and those without metastasis in lymph nodes other than SLN. In the subgroup of patients with G3 tumors, $64.81 \%$ had non-SLN with metastasis compared to $47.42 \%$ in the subgroup with G1-2 tumors ( $p=0.004$ ). Consistently, among patients with metastasis only $4.54 \%$ were grade 1 versus $21.61 \%$ among those without other lymph nodes involved. 
Considering tumor size, figure $1 \mathrm{~B}$ shows that $69.67 \%$ of patients with T2 tumors had positive non-SLN while only $47.09 \%$ of T1 patients presented with positive non-SLN $(\mathrm{p}<0.001)$. Likewise, when analyzing the proportion of $\mathrm{T} 2$ tumors in the groups with positive versus negative non-SLN, evident disparity was observed (46.7 vs. 25.34\%).

Figure 1C presents the relationship between age and non-SLN positivity. Patients older than 50 years revealed positive non-SLN

Table 2. Univariate analysis of factors associated with non-sentinel lymph node (SLN) positivity

\begin{tabular}{llll}
\hline Variables & $\begin{array}{l}\text { Odds } \\
\text { ratio }\end{array}$ & $\begin{array}{l}\text { 95\% confidence } \\
\text { interval }\end{array}$ & p value \\
\hline Histological grade (3 vs. 1-2) & 2.04 & $1.26-3.32$ & 0.004 \\
Size (T2 vs. T1) & 2.58 & $1.61-4.14$ & $<0.001$ \\
Age > 50 years & 1.86 & $1.18-2.92$ & 0.007 \\
Postmenopausal status & 2.08 & $1.30-3.32$ & 0.002 \\
Lymphovascular invasion & 1.22 & $0.77-1.91$ & 0.40 \\
Estrogen receptor-positive & 0.59 & $0.30-1.17$ & 0.11 \\
Progesterone receptor-positive & 0.68 & $0.37-1.23$ & 0.20 \\
HER2-positive & 1.42 & $0.73-2.77$ & 0.31 \\
Luminal phenotype & 0.63 & $0.35-1.12$ & 0.11 \\
Ductal subtype & 1.42 & $0.84-2.42$ & 0.19 \\
Macrometastasis in SLN & 1.34 & $0.81-2.42$ & 0.26 \\
Only 1 SLN resected & 0.95 & $0.61-1.47$ & 0.82 \\
\hline
\end{tabular}

Table 3. Multivariate analysis of factors associated with non-sentinel lymph node (SLN) positivity

\begin{tabular}{llll}
\hline Variables & $\begin{array}{l}\text { Odds } \\
\text { ratio }\end{array}$ & $\begin{array}{l}\text { 95\% confidence } \\
\text { interval }\end{array}$ & p value \\
\hline Histological grade (3 vs. 1-2) & 1.81 & $1.08-3.04$ & 0.024 \\
Size (T2 vs. T1) & 2.39 & $1.42-4.04$ & 0.001 \\
Age $>50$ years & 1.95 & $1.20-3.18$ & 0.007 \\
\hline
\end{tabular}

in $61.27 \%$, while only $45.97 \%$ of the subjects aged $\leq 50$ years had positive non-SLN ( $\mathrm{p}=0.007$ ). Also, the proportion of older patients significantly differed between patients with positive versus negative non-SLN (68.68 vs. $54.11 \%$ ).

Due to the direct correlation between age and postmenopausal status $(95.5 \%$ of patients older than 50 years were postmenopausal), we decided to include in the logistic regression model only 3 variables: histological grade, tumor size, and age. The results of the multivariate analysis are shown in table 3 and show that for each patient without these characteristics that have positive non-SLN, 2 patients with these variables present with positive non-SLN (OR $1.81,2.39$, and 1.95 , respectively).

\section{Discussion}

Currently, it is widely accepted that ALND does not improve survival in patients with negative SLN or micrometastatic disease $[13,14]$. ACOSOG Z0011 presented practice-changing results that need to be carefully analyzed. The trial included a highly selected group of patients with T1-2 tumors, treated with BCS and SLNB with resulting positivity in less than 3 nodes. This was a low-risk population that received adjuvant treatment (radiotherapy \pm chemotherapy \pm endocrine therapy) aimed at controlling eventual persistence of axillary metastasis. However, some confusion has been generated, pertaining to the application of these findings without satisfying the strict trial criteria. Publications related to the changes generated by these results in countries like Spain include patients with mastectomy and SLN positivity not receiving ALND in 10.96\% [15]. Adequate analyses have shown that in European centers less than $10 \%$ of patients could benefit from this practice $[5,16]$, equating to $8.12 \%$ of the patients with SLN detection in our analysis. However, this population comprises $35 \%$ of the patients with positive SLN biopsy, making them candidates for avoiding ALND.
Fig. 1. Proportion of non-sentinel lymph node (SLN) positivity according to $\mathbf{A}$ histological grade (bar chart shows statistical differences), $\mathbf{B}$ tumor size (bar chart shows statistical differences), $\mathbf{C}$ age group (bar chart shows statistical differences).
A

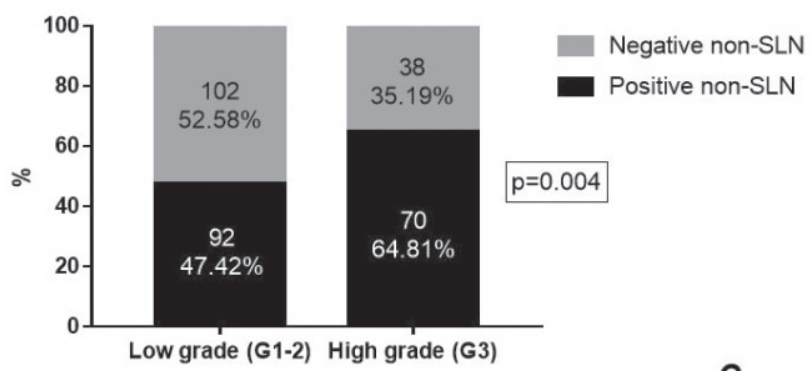

C
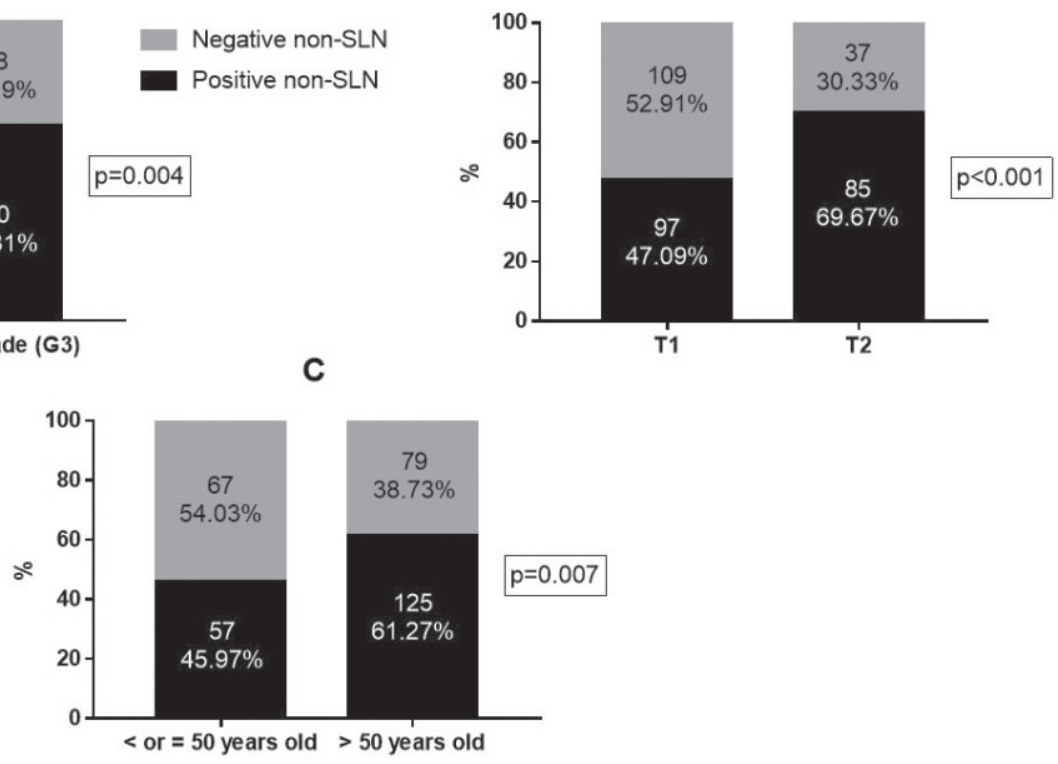

Loza et al. 
Our study also provides information on the degree to which the ACOSOG Z0011 population is representative of patients undergoing primary BCS for clinical T1/T2 node-negative breast cancers. In our patient cohort, after refining its characteristics according to the inclusion and exclusion criteria, patient and tumor characteristics were similar to those of the women enrolled in ACOSOG Z0011. Similarities exist for age ( 55 vs. 55 years), proportion of T2 ( 36 vs. $31 \%$ ), hormone receptor negativity (15 vs. $16 \%$ ), and lymphovascular invasion (45 vs. $40 \%$ ). Important differences can be seen in the rate of micrometastatic disease in the SLN and the rate of non-SLN positivity. In our population, the latter was 52.3\%, while it was only $27 \%$ in ACOSOG Z0011 patients and 33\% in the AMAROS trial [17]. Our results are similar to those reported by several authors for European [18] and Argentinian cohorts [19, 20] ranging from 44 to $59 \%$, and a 2006 meta-analysis including more than 8,000 patients described a positivity rate of $53 \%$ [21]. We understand that the difference compared to these 2 important trials resides in the great variation in micrometastatic disease, as our cohort presented with only $13.5 \%(n=47)$ of positive SLN due to micrometastasis compared to $37.5 \%(\mathrm{n}=137)$ in ACOSOG and $29 \%(\mathrm{n}=215)$ in AMAROS.

Patients with more aggressive tumor phenotypes such as estrogen receptor-negative or HER2-positive tumors were not more likely to have extensive nodal disease. This supports previous evidence from different studies in which patients with these tumor types did not show differences in axillary cancer burden although presenting a greater risk of recurrence and poor prognosis [22, 23]. Therefore, these patients should not be excluded from being given the option of avoiding ALND.

Positivity of non-SLN is the accepted risk when deciding not to pursue ALND in the case of metastatic SLN. As has been stated before, the percentage of patients with residual disease is variable depending on the cohort described. Hence, promoting this practice as a standard requires an exhaustive evaluation in order to adequately select those patients who are suitable candidates and will benefit from avoiding further surgery without affecting long-term prognosis. Evidence from past studies has demonstrated that certain clinical or pathological characteristics of breast tumors increase the risk of nodal involvement. Series agree in terms of tumor size, histological grade, lymphovascular invasion, number of SLN resected, macrometastatic nodal disease, and extracapsular extension as predictive factors [6-12]. Furthermore, some of these analyses have proposed and developed the use of nomograms to estimate the risk of metastatic disease in axillary nodes in order to define if ALND is needed [24, 25].
The application of this less invasive approach to axillary management involves the understanding that low-volume residual disease in the axilla will be treated with tangent field irradiation and systemic therapy. This concept is based on the evidence generated by 2 important scenarios: i) recurrence rate in patients with radiotherapy and endocrine therapy having no axillary surgery [26-28] and ii) axillary complete response rate in neoadjuvant treatment [29]. Trials on avoiding ALND such as ACOSOG Z0011 or IBCSG 23-01 suggest that regional recurrence is low even in patients with untreated additional nodal metastasis (13-27\%) [2, 30].

Our database analysis is the first in Argentina to specifically assess patients according to ACOSOG Z0011 criteria. It has shown that patients older than 50 years with T2 or histological grade 3 tumors have a 2-fold risk of nodal disease being left untreated if ALND is avoided. This analysis has important limitations as it is based on retrospective data from a national database, which may favor certain errors and mislead data interpretation. Consequently, prognostic relevance is missing, but our results support the understanding of the situation and epidemiology in Latin-American countries. Argentina as many of its neighbors does not have adequate screening programs, and diagnosis and treatment may vary compared to developed countries. Thoroughly understanding our population may allow us to tailor therapy and make optimal decisions similar to the practice in developed countries. Survival results of ACOSOG Z0011 with 10-year follow-up have proven that prognosis is not affected by the decision for or against ALND [31]; however, patients presenting with T2 or histological grade 3 tumors were scarcely represented.

\section{Acknowledgement}

Centers collaborating with RCM: Hospital Penna (CABA), Hospital Fernandez (CABA), Hospital Marie Curie (CABA), Breast Clínica de la Mama (La Plata, Buenos Aires), Hospital Piñero (CABA), Instituto de Oncología 'Angel Roffo' (CABA), Instituto Alexander Fleming (CABA), Hospital Rivadavia (CABA), Hospital Aeronáutico Central (CABA), Hospital Naval 'Cirujano Mayor Pedro Mallo' (CABA), Sanatorio Modelo de Caseros (Buenos Aires), Hospital Posadas (Buenos Aires), Corporación Médica San Martín (Buenos Aires), Hospital Nacional de Clínicas (Córdoba), IMGO (Córdoba), Hospital Centro de Salud (Tucumán), Sanatorio Adventista del Plata (Entre Ríos) y Hospital de la Madre y el Niño.

\section{Disclosure Statement}

The authors declare that they have no competing interests. There has been no study sponsor involvement in the study design or collection, analysis, and interpretation of data, nor in the writing or submission of the manuscript for publication.

\section{References}

1 Reynolds C, Mick R, Donohue JH, Grant CS, Farley DR, Callans LS, Orel SG, Keeney GL, Lawton TJ, Czerniecki BJ: Sentinel lymph node biopsy with metastasis: can axillary dissection be avoided in some patients with breast cancer? J Clin Oncol 1999;17:1720-1726.
2 Giuliano AE, Hunt KK, Ballman KV, Beitsch PD, Whitworth PW, Blumencranz PW, Leitch AM, Saha S, McCall LM, Morrow M: Axillary dissection vs no axillary dissection in women with invasive breast cancer and sentinel node metastasis: a randomized clinical trial. Jama 2011;305:569-575.
3 Giuliano AE, Morrow M, Duggal S, Julian TB: Should ACOSOG Z0011 change practice with respect to axillary lymph node dissection for a positive sentinel lymph node biopsy in breast cancer? Clin Exp Metastasis 2012;29:687-692. 
4 Shah-Khan M, Boughey JC: Evolution of axillary nodal staging in breast cancer: clinical implications of the ACOSOG Z0011 trial. Cancer Control 2012;19:267-276.

5 Güth U, Myrick M, Viehl C, Schmid S, Obermann E, Weber W: The post ACOSOG Z0011 era: does our new understanding of breast cancer really change clinical practice? Eur J Surg Oncol 2012;38:645-650.

6 Den Bakker MA, Van Weeszenberg A, De Kanter A, Beverdam F, Pritchard C, van der Kwast TH, MenkePluymers M: Non-sentinel lymph node involvement in patients with breast cancer and sentinel node micrometastasis; too early to abandon axillary clearance. J Clin Pathol 2002;55:932-935.

7 Hwang RF, Krishnamurthy S, Hunt KK, Mirza N, Ames FC, Feig B, Kuerer HM, Singletary SE, Babiera G, Meric F: Clinicopathologic factors predicting involvement of nonsentinel axillary nodes in women with breast cancer. Ann Surg Oncol 2003;10:248-254.

8 Saidi RF, Dudrick PS, Remine SG, Mittal VK: Nonsentinel lymph node status after positive sentinel lymph node biopsy in early breast cancer. Am Surg 2004;70: 101-105, discussion 105.

9 Joseph K-A, El-Tamer M, Komenaka I, Troxel A, Ditkoff BA, Schnabel F: Predictors of nonsentinel node metastasis in patients with breast cancer after sentinel node metastasis. Arch Surg 2004;139:648-651.

10 Wong SL, Edwards MJ, Chao C, Tuttle TM, Noyes RD, Woo C, Cerrito PB, McMasters KM: Predicting the status of the nonsentinel axillary nodes: a multicenter study. Arch Surg 2001;136:563-568.

11 Ozmen V, Karanlik H, Cabioglu N, Igci A, Kecer M, Asoglu O, Tuzlali S, Mudun A: Factors predicting the sentinel and non-sentinel lymph node metastases in breast cancer. Breast Cancer Res Treat 2006;95:1-6.

12 Kwon Y, Ro J, Kang H-S, Kim SK, Hong EK, Khang SK, Gong G, Ro JY: Clinicopathological parameters and biological markers predicting non-sentinel node metastasis in sentinel node-positive breast cancer patients. Oncol Rep 2011;25:1063-1071.

13 Krag DN, Anderson SJ, Julian TB, Brown AM, Harlow SP, Costantino JP, Ashikaga T, Weaver DL, Mamounas EP, Jalovec LM: Sentinel-lymph-node resection compared with conventional axillary-lymph-node dissection in clinically node-negative patients with breast cancer: overall survival findings from the NSABP B-32 randomised phase 3 trial. Lancet Oncol 2010;11:927-933.

14 Mansel RE, Fallowfield L, Kissin M, Goyal A, Newcombe RG, Dixon JM, Yiangou C, Horgan K, Bundred N, Monypenny I: Randomized multicenter trial of sentinel node biopsy versus standard axillary treatment in operable breast cancer: the ALMANAC Trial. J Natl Cancer Inst 2006;98:599-609.
15 Nebril BA, Novoa AG, Garea CC, Villar RR, Freijanes PS, Martínez LC, Novoa SA, Silva C, Candal I, Calviño BL: Repercusión de los criterios ACOSOG Z0011 sobre la indicación de la linfadenectomía axilar y el control locorregional en mujeres con ganglio centinela metastásico. Resultados preliminares tras cuatro años de aplicación clínica. Revista de Senología y Patología Mamaria 2015;28:105-112.

16 Yeow W-C, Thomee E, Roche N, MacNeill F, Rusby J: ACOSOG Z0011: are the results applicable to patients undergoing sentinel node biopsy in a UK breast unit. Eur J Surg Oncol 2011;37:S11-S12.

17 Straver ME, Meijnen P, van Tienhoven G, van de Velde CJ, Mansel RE, Bogaerts J, Duez N, Cataliotti L, Klinkenbijl JH, Westenberg HA: Sentinel node identification rate and nodal involvement in the EORTC 10981-22023 AMAROS trial. Ann Surg Oncol 2010;17: 1854-1861.

18 Rahusen FD, Torrenga H, van Diest PJ, Pijpers R, van der Wall E, Licht J, Meijer S: Predictive factors for metastatic involvement of nonsentinel nodes in patients with breast cancer. Arch Surg 2001;136:10591063.

19 Beccar Varela E, McLean I, Mosto J, et al: Ganglio cen tinela positivo en pacientes con cáncer de mama: análisis de factores de riesgo para resultados positivos en el resto de la axila. Experiencia del centro mamario del Hospital Universitario Austral. Rev Arg Mastol 2011; 30:349-358.

20 Isetta J, Candás G, García A, et al: Factores de predicción del compromiso ganglionar axilar no centinela en casos de ganglio centinela positivo. Rev Arg Mastol 2012;31:403-413.

21 Kim T, Giuliano AE, Lyman GH: Lymphatic mapping and sentinel lymph node biopsy in early-stage breast carcinoma. Cancer 2006;106:4-16.

22 Ugras S, Stempel M, Patil S, Morrow M: Estrogen receptor, progesterone receptor, and HER2 status predict lymphovascular invasion and lymph node involvement. Ann Surg Oncol 2014;21:3780-3786.

23 Viale G, Zurrida S, Maiorano E, Mazzarol G, Pruneri G, Paganelli G, Maisonneuve P, Veronesi U: Predicting the status of axillary sentinel lymph nodes in $4351 \mathrm{pa}-$ tients with invasive breast carcinoma treated in a single institution. Cancer 2005;103:492-500.

24 Chen JY, Chen JJ, Xue JY, Chen Y, Liu GY, Han QX, Yang WT, Shen ZZ, Shao ZM, Wu J: Predicting nonsentinel lymph node metastasis in a Chinese breast cancer population with 1-2 positive sentinel nodes: development and assessment of a new predictive nomogram. World J Surg 2015;39:2919-2927.
25 Liu M, Wang S, Pan L, Yang D, Xie F, Liu P, Guo J, Zhang J, Zhou B: A new model for predicting nonsentinel lymph node status in Chinese sentinel lymph node positive breast cancer patients. PloS One 2014; 9:e104117.

26 Martelli G, Miceli R, Daidone MG, Vetrella G, Cerrotta AM, Piromalli D, Agresti R: Axillary dissection versus no axillary dissection in elderly patients with breast cancer and no palpable axillary nodes: results after 15 years of follow-up. Ann Surg Oncol 2011;18: 125-133.

27 International Breast Cancer Study Group; Rudenstam $\mathrm{CM}$, Zahrieh D, et al: Randomized trial comparing axillary clearance versus no axillary clearance in older patients with breast cancer: first results of International Breast Cancer Study Group Trial 10-93. J Clin Oncol 2006;24:337-344

28 Veronesi U, Orecchia R, Zurrida S, Galimberti V, Luini A, Veronesi P, Gatti G, D'aiuto G, Cataliotti L, Paolucci R: Avoiding axillary dissection in breast cancer surgery: a randomized trial to assess the role of axillary radiotherapy. Ann Oncol 2005;16:383-388.

29 Gralow JR, Burstein HJ, Wood W, Hortobagyi GN, Gianni L, von Minckwitz G, Buzdar AU, Smith IE, Symmans WF, Singh B: Preoperative therapy in invasive breast cancer: pathologic assessment and systemic therapy issues in operable disease. J Clin Oncol 2008; 26:814-819.

30 Galimberti V, Cole BF, Zurrida S, Viale G, Luini A, Veronesi P, Baratella P, Chifu C, Sargenti M, Intra M: Axillary dissection versus no axillary dissection in patients with sentinel-node micrometastases (IBCSG 2301): a phase 3 randomised controlled trial. Lancet Oncol 2013;14:297-305.

31 Giuliano AE, Ballman KV, McCall L, Beitsch PD, Brennan MB, Kelemen PR, Ollila DW, Hansen NM, Whitworth PW, Blumencranz PW: Effect of axillary dissection vs no axillary dissection on 10 -year overall survival among women with invasive breast cancer and sentinel node metastasis: the ACOSOG Z0011 (Alliance) randomized clinical trial. JAMA 2017;318:918926. 